\title{
Analysis of Former Athlete Coaching Model in Indonesia:
}

\author{
A preliminary study \\ Nuryadi Nuryadi*, Yusuf Hidayat, Dian Budiana, Jajat Darajat K Negara \\ The Faculty of Sport and Health Education \\ Universitas Pendidikan Indonesia \\ *nuryadi_71@upi.edu
}

\begin{abstract}
Post-athlete careers are a phenomenon that attracts public attention, not only in terms of success but also in terms of failure of former athletes in living the life of retirement from the status of athletes. This preliminary study aims to look at the post-athlete career coaching model. The research method uses survey techniques carried out on the Sports Committee in Indonesia. The instrument used is a scale developed based on the theory of Career Development which consists of six transitional periods (1) Beginning and then specification of sports, (2) Intensive training in a sport, (3) Transfer from junior to senior to gain peak performance, (4) Transition from amateur status to professional, (5) From peak performance to final period, (6) Retirement. The results of the analysis of the survey of 20 Sports Committees showed that $25 \%$ of the Sports Committee carried out the initial coaching to the specifications of the sport, $89 \%$ of the Sports Committee carried out coaching intensive training in a sport, $95 \%$ of the Sports Committee carried out coaching from the junior to the senior to achieve top performance, The $95 \%$ Sports Committee carries out the transition from amateur to professional status, $30 \%$ of the Sports Committee carries out coaching from peak to final and $0 \%$ of Sports Committees carry out retirement or post-athlete careers.
\end{abstract} model

Keywords-career development; former athletes; coaching

\section{INTRODUCTION}

One of the most frequently found issues of a former athlete is their career post their athlete career. In addition, their transitional period is also a critical time athletes face. In relation to this, the Chinese government has implemented a policy for former athletes. As much as $10 \%$ of their former athletes are offered an opportunity to work in the government. To do so, they have to wait for a year or two $[1,2]$. In Indonesia, the government has not made a national policy for the career of former athletes. Some of the regional governments have their own policies which are not sustainable such as giving rewards for certain accomplishments. In addition, universities with sports faculties also do not have programs dealing with the issue.

There are several coaching models developed. One of which is namely Long-Terms Athlete Development (LTAD) by Canadian Sport Center tried out in 1999-2000. The model implements seven stages of coaching starting from children aged 0-6 years old or active start to the stage called active for life. The stages are shown in Figure 1.

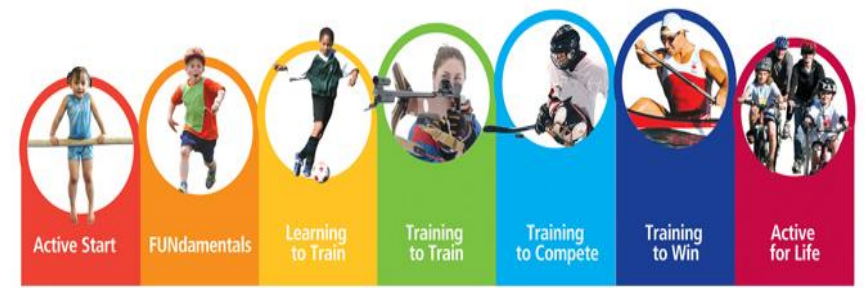

Fig. 1. LTAD Sport coaching model, model developed by Canadian Sport Center.

Figure 1 shows that the coaching of competitive sport needs a long time, starting from early ages and lasting even after the athletes retire. The time needed to be champions are also various (probably 10-20 years) depends on the sport they do [35]. In Indonesia, the coaching models stops at training to win. Thus, the athletes who are about to retire or those who already retire do not have enough coaching and education.

It is believed that career development is proceeding through the stages and transition of career. In other words, career has to get through several stages. In this context, there are six career stages including (1) the beginning and specification of sport; (2) intensive training; (3) transition from juniors to seniors; (4) transition from amateurs to professionals; (5) the peak of achievement; and (5) retirement period [4,5]. Thus, this study aimed to identify the description of coaching models for athletes and former athletes by the sport central clubs in Indonesia.

\section{RESEARCH METHOD}

\section{A. Participants}

This study employed a survey method. The survey was conducted to the members of central sport clubs in Indonesia using an interview technique. The number of sport clubs selected was 20 which was chosen using a snowball sampling technique. 


\section{B. Research Instruments}

The instrument used in this study was a questionnaire on athlete career development model by Stambulova consisting of six indicators as follows (1) the beginning and specification of sport; (2) intensive training; (3) transition from juniors to seniors; (4) transition from amateurs to professionals; (5) the peak of achievement; and (5) retirement period [4].

\section{Data Analysis Technique}

The data were analyzed using percentage aiming at investigating the clear description by the respondents on the coaching model by each of the clubs studied. In addition, a one way Anova test was also used to see the comparison among the indicators so that the statistical analysis will show which indicators are significant.

\section{RESULTS}

Based on the six indicators of the coaching model in this study, the results showed various percentage as shown in Table 1.

TABLE I. ANALYTICAL RESULTS OF THE IMPLEMENTATION OF ATHLETE TRANSITIONAL PERIOD COACHING

\begin{tabular}{|l|c|c|}
\hline \multicolumn{1}{|c|}{ Indicator } & Implemented & Not implemented \\
\hline Indicator 1 & $25 \%$ & $75 \%$ \\
\hline Indicator 2 & $89 \%$ & $11 \%$ \\
\hline Indicator 3 & $95 \%$ & $5 \%$ \\
\hline Indicator 4 & $95 \%$ & $5 \%$ \\
\hline Indicator 5 & $50 \%$ & $50 \%$ \\
\hline Indicator 6 & $15 \%$ & $85 \%$ \\
\hline
\end{tabular}

The percentage is presented in a diagram as presented in Figure 2 .

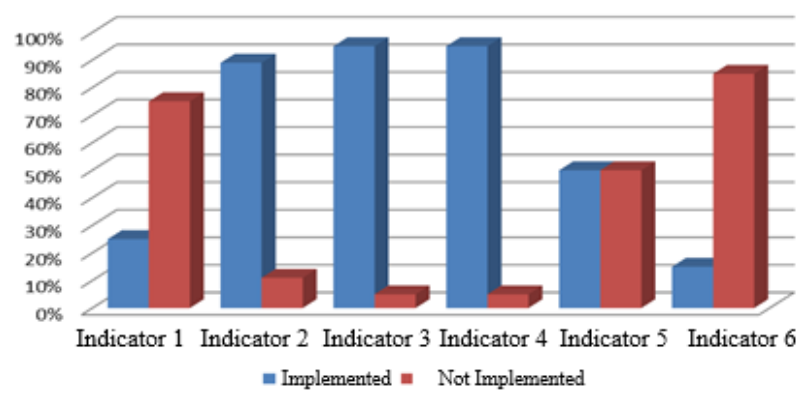

Fig. 2. Description of athlete transitional period coaching model implementation.

In the meantime, the statistical description of athlete career development coaching model is shown in Table 2.

TABLE II. STATISTICAL DESCRIPTION OF ATHLETE CAREER DEVELOPMENT COACHING MODEL

\begin{tabular}{|c|c|c|c|c|}
\hline Indicator & $\mathbf{N}$ & Mean & Std. Deviation & Std. Error \\
\hline Indicator 1 & 20 & 1.25 & 0.44 & 0.10 \\
\hline Indicator 2 & 20 & 3.00 & 0.97 & 0.22 \\
\hline Indicator 3 & 20 & 2.55 & 0.76 & 0.17 \\
\hline Indicator 4 & 20 & 3.05 & 0.76 & 0.17 \\
\hline Indicator 5 & 20 & 1.80 & 0.62 & 0.14 \\
\hline Indicator 6 & 20 & 1.70 & 1.03 & 0.23 \\
\hline
\end{tabular}

Remarks:

Indicator $1=$ The beginning of sport speficiation

Indicator $2=$ Intensive training

Indicator 3 = Transition from juniors to seniors

Indicator $4=$ Transition from amaterus to professionals

Indicator $5=$ Peak of achivement to the end of the career

Indicator $6=$ Retirement era

TABLE III. RESUlts OF ONE WAY ANNOVA AMONG the SX INDICATORS

\begin{tabular}{|l|c|c|c|c|c|}
\hline & Sum of Squares & df & $\begin{array}{c}\text { Mean } \\
\text { Square }\end{array}$ & F & Sig. \\
\hline Between Groups & 55.88 & 5 & 11.18 & 17.93 & 0.00 \\
\hline Within Groups & 71.05 & 114 & 0.62 & & \\
\hline Total & 126.93 & 119 & & & \\
\hline
\end{tabular}

Table 3 inferred that there are some clubs who are not implementing the coaching for athlete transitional career.

\section{DISCUSSION}

This preliminary study found out that $15 \%-95 \%$ of the respondents stated that the coaching model was implemented and 5\%-85\% stated that it was not implemented. In the first stage, the percentage indicated that the central sport clubs did not implement the sport specification guidance since the regional clubs did it so that the central clubs just monitored the process. The next stage, which was intensive training, reached a high percentage $(89 \%)$ indicating that the training was successfully implemented by the central sport clubs. Regarding the training from juniors to seniors, the percentage was quite high as well (95\%) meaning that the central sport clubs did it well. This number also applied for the coaching model from amateurs to professionals. The coaching model from the peak achievement period to the end of the career is 50\% meaning that it needs to be improved. Last but not least, the coaching model in the retirement period was only implemented by $15 \%$ of the respondents proving that this period was a critical period in need of serious attention.

This result was supported by the results of the statistical analyses starting from the $F$ value of 17.93 at $p$ value of 0.00 . This means that there is a significant difference of the implementation of the coaching in the transitional period. In addition, the difference of mean in the beginning and retirement eras indicated that the coaching model in the retirement era was not implemented.

The findings of this study proved that there has not been an ideal model of coaching within the retirement era. As a matter of fact, the retirement period is a critical period where it is often considered a social death [6] reflected by isolation and rejection from their previous groups [7]. In Canada, it has been found that $78 \%$ of their retiring athletes faced emotional difficulties after leaving their sport and the rest of $32 \%$ of them stated that the transitional period was extremely difficult [8]. It was also reported that one-third of retiring athletes, either amateurs or professionals had serious issues related to finance 
and psychology. Additionally, $11 \%$ of the retiring athletes were not satisfied with their lives after retirement and $15 \%$ of them thought that they could not handle their issues of career transition [9].

Thus, it is recommended that future studies focus on developing coaching models within the transitional period of the athletes since the role of the athletes are important. To do so, the government also needs to come up with a national policy obliging the athletes to have good education and training since both are most important investments in human capital.

\section{CONCLUSION}

Based on the results of the study, it is found that most of the central sport clubs in Indonesia have not implemented coaching models to athletes in their transitional period of their career so that most of the athletes face difficulties in their retirement period. Furthermore, there needs to be a collaborative work between the government, universities, and all parties involved to have an ideal coaching models for former athletes candidates.

\section{REFERENCES}

[1] Z. Liu and Y. Lu, "Re-Employment of Retired Athletes in China," The International Journal of the History of Sport, vol. 33, pp. 624-633, 2016.

[2] I. Balyi and A. Hamilton, "Long-term athlete development: trainability in childhood and adolescence," Olympic Coach, vol. 16, pp. 4-9, 2004

[3] N. Stambulova, D. Alfermann, T. Statler and J.E.A.N. CôTé, "ISSP position stand: Career development and transitions of athletes," International journal of sport and exercise psychology, vol. 7, pp. 395412, 2009.

[4] N. Stambulova, "Counseling athletes in career transitions: The five-step career planning strategy," Journal of Sport Psychology in Action, vol. 1, pp. $95-105,2010$

[5] T.V. Ryba, N.B. Stambulova, N.J. Ronkainen, J. Bundgaard and H. Selänne, "Dual career pathways of transnational athletes," Psychology of Sport and Exercise, vol. 21, pp. 125-134, 2015.

[6] R.C. Atchley, The social forces in later life: An introduction to social gerontology. CA: Wadsworth Publishing Company, 1980.

[7] E. Rosenberg, "Athletic retirement as social death: Concepts and perspectives," Sport and the sociological imagination, pp. 245-258, 1984.

[8] P. Werthner and T. Orlick, "Retirement experiences of successful Olympic athletes," International journal of sport psychology, 1986.

[9] D.A. Sinclair and T. Orlick, "Positive transitions from high-performance sport," The sport psychologist, vol. 7, pp. 138-150, 1993. 